\title{
Application of Role Play Learning Method In Increasing Morality Of Islamic Integrated Primary School Students in the Subject of Islamic Religious Education
}

\author{
Yuli Asmi Rozali ${ }^{1}$, Novendawati Wahyu Sitasari ${ }^{2}$, Ikbal Rahmat ${ }^{3}$, Abdur Rahman ${ }^{4}$ \\ \{yuli.azmi@esaunggul.ac.id ${ }^{1}$, novenda@esaunggul.ac.id ${ }^{2}$,ikbal.rachmat@esaunggul.ac.id ${ }^{3}$, \\ abdurrahman.jemat@esaunggul.ac.id ${ }^{4}$ \} \\ Universitas Esa Unggul, Jakarta ${ }^{1,2,3,4}$
}

\begin{abstract}
Education is one of the gates for shaping the morality of the nation's children, in formal, informal and non-formal education. Elementary school is the initial foundation for the moral development of students. At school, student moral formation is carried out through daily subjects such as Islamic religious education, from the elementary school level to the university level. Through religious education, the government hopes to shape the character of good youth by the principles that depend upon religion. Many factors can influence learning achievement, one of which is the learning method, one of which is the role-playing method. The type of this study was a quasi-type two-group pretest-posttest experiment. The study population was students of the Islamic Integrated Primary School in Jakarta. The analytical method uses a difference t-test, which compares the significance value with table $t$, with significance requirements (sig.) $(\mathrm{P})=<0.05$, with an error rate of $5 \%$. Based on the results of processing the t-test, a significance value of $(\mathrm{p})=0.000 ;((\mathrm{p})$ $<0.05)$ was obtained, meaning that there is a difference in the morality level of Jakarta Islamic elementary school students based on giving role-playing learning methods. The magnitude of the mean value possessed by the two groups shows the mean of the experimental group is greater $(\mu=11,000)$ when compared to the mean of the control group $(\mu=10,000)$. This means that the experimental group has a higher level of morality than the control group.
\end{abstract}

Keywords: role-playing teaching method, morality, elementary students, Islamic education

\section{Introduction}

The young generation is the hope for a nation. The progress of a nation lies in the quality of the nation's children. The young generation has important roles and functions in the nation and state development. Therefore, the next generation must have a strong morality, strong personality, and a spirit of nationalism to be able to compete globally. In addition to having the function of moral strength, the younger generation also becomes a social control an agent of change for a nation, so that it can function for the wider community.

The active role of the young generation as a moral force is realized by the development of aspects of ethics and morality in acting in every dimension of life, strengthening faith, having mental health and flourishing psychologically. 
Globalization is one of the strategic breakthroughs that can affect the values of a nation, including the Indonesian people. Some people argue that globalization can shift the values and traditions of the Indonesian people. If the younger generation is unable to fight the era of globalization, if it is unable to filter the information that exists, it will have an impact on the beliefs and morality of the young generation itself.

In fortifying the young generation, students especially need strong morals. Education is one of the gates in shaping the morality of the nation's children, in formal, informal and non-formal education. At the level of nonformal and informal education, the moral formation can be done in the social environment of students such as family and peers. Whereas in the level of formal education, student moral formation is carried out through daily subjects such as religious education and civics, from the elementary school level to the university level. Elementary school is the initial foundation for the moral development of students.

Primary education has a significant role and responsibility in responding to actual developments in the formation of the child's mindset and morality. Primary education, as one of the levels of education in the national education system, can be likened to an entrance ticket or "passport" to continue to the next trip. The failure of education at this stage, especially in fostering attitudes/values, is believed to have a systemic impact on subsequent education. The orientation of the implementation of primary education heavily stresses fostering the personality, character, and character of the child. Therefore, the integration of education that is full of values and character formation is needed to equip students to anticipate future challenges that will undoubtedly be increasingly heavy and complex. The teacher who develops curriculum is required to be able to skillfully present a learning atmosphere and activities that are oriented towards planting and fostering personality, temperament, and character.

Religious education is one of the subjects that is mandatory for all students. Islamic studies are studied by students who are Muslim, and Christian education is studied by students who are Christian. Similarly, Hindu and Buddhist education are attended by students who are Hindu and Buddhist, respectively. Similarly to other kinds of religious education, in Islamic studies, the students are taught to become human beings who believe and fear the Almighty God, namely Allah S.W.T., as well as having a noble character. A noble character includes ethics, character, or morals as an embodiment of religious education [1].

Through religious education, the government hopes to shape the character of moral youth by the rules that depend on religion, so that a good creature may be formed. However, the reality in the field is that there are still many students who are not moral by the objectives of Islamic education. This is shown by the rampant deviant behavior carried out by students that include undisciplined behavior which violates rules and order.

Of the many factors that can influence learning achievement, one is the learning method which is used by teachers who teach religious education. This is in line with the results of research conducted by Sumadji (2015), regarding the effect of learning methods on student learning outcomes, which results in the influence of learning methods on student learning outcomes. Additionally, the results of the research conducted by Suryastuti (2013), regarding the effect of learning methods and teacher performance on the learning achievement, of class X students of Social Sciences subjects in Prembun Kebumen Primary Vocational High School, showed that there were influences of learning methods and teacher performance on student learning achievement in class X, social studies subjects at Prembun Kebumen Vocational High School.

From the results of the above research, it can be concluded that the learning method has a role in the learning success of the students. Santrock (2010) found that there are two types of learning methods, namely teachercentered learning methods (TCL), and student-centered learning methods (SCL). In the TCL learning system, students are passive because they only act as recipients, while the center of learning is in the teacher. On the other hand, in the SCL learning system, the learning process is more student-centered, and the teacher has fewer roles, primarily as a controller of the learning process and a facilitator. In SCL learning, students are trained to build their knowledge, find information through their classmates, discuss, and role play.

The results of research conducted by [2] regarding the differences in learning motivation were reviewed from experience-based learning (studies on psychometric class students at Esa Unggul University), which were also supported by the results of Ardian and Munadi's study (2015), regarding the effect of SCL learning strategies and spatial ability of student creativity, has proven that the SCL learning method can increase learners' motivation and creativity. Based on the description of the problem above, which is also supported by previous studies, the researchers wanted to see the effect of the role play learning method on moral development in Class V Elementary School Students in an Islamic education class.

\section{$2 \quad$ Literature Review}

Role-playing is a teaching strategy that fits within the social family of models [3]. These strategies emphasize the social nature of learning and see cooperative behavior as stimulating students both socially and intellectually. Role-playing as a teaching strategy offers several advantages for both teacher and student. First, student interest in the topic is raised. Research has shown that "integrating experiential learning activities in the classroom increases interest in the subject matter and understanding of course content" [4]. Tells of a college professor who 
felt that his history classes were boring and not involving the students [5]. After trying out a role-playing type game one semester, he observed that students were much more interested in the material. Secondly, there is increased involvement on the part of the students in a role-playing lesson. Students are not passive recipients of the instructor's knowledge. Rather, they take an active part. Observes that "true learning cannot take place when students are passive observers of the teaching process" [4]. One student at Barnard College who was enrolled in a role-playing history class said, "This class tricks you into doing so much work" [5]. The result of the involvement is increased learning [5]. A third advantage of using role-playing as a teaching strategy is that it teaches empathy and understanding of different perspectives [4]. A typical roleplaying activity would have students taking on the role of a character, learning and acting as that individual would do in the typical setting. Poorman found "a significant increase among students in feeling another's distress as their own" [4]. Role-playing has also been seen to be effective in reducing racial prejudice [6]. Students who role-play the part of enslaved African Americans in a class on pre-Civil War history, for example, develop greater empathy and come away with a better idea of the experience than they would in a typical lecture setting [7].

In role-playing, the student is representing and experiencing a character known in everyday life [8]. The use of role-playing emphasizes personal concerns, problems, behavior, and active participation (Silver \& Silver, 1989). It improves interpersonal skills [9], improves communication skills [10], and enhances communication [11]. The role-playing approach can be used in a variety of settings, including the classroom. The principle behind role-playing is that the student assumes a particular personality of a different person, such as a historical character. According to [12], students "must accept the duties and responsibilities of their roles and functions, and do the best they can in the situation in which they find themselves." One possible use of role-playing might be to introduce a topic, using the students' background knowledge (schema) to introduce and interest them in a new unit of study [13].

However, probably more often, role-playing is used as a strategy in which students use their background knowledge in addition to acquiring new information about the character in order to better play the role [13]. Skilled teachers have generally used skits, plays, newscasts, and other forms of drama to motivate students when new information introduced. Role-playing activities can be divided into four stages [14] preparation and explanation of the activity by the teacher, student preparation of the activity, the role-playing, the discussion or debriefing after the role-play activity.

\section{Method}

This research is a quasi-experimental study, define in two-group pretest-posttest. An experimental group is a group that will be given treatment or manipulation as a role-playing learning method, while the control group is a group that does not get treatment which will also be used as a comparison group and also to know the accuracy of the role play method to increase student morality level.

\subsection{Sample}

The population in Islamic student Elementary School, in Jakarta and participant Pendidikan Agama Islam. This research to be done in Al Mukhlisin Elementary School as an experiment group and An Najjah Elementary School as a control group.

\subsection{Measurement Tools}

This study used role-playing learning modules, and also the Moral Level questionnaire from Kohlberg [15]. The moral level scale is constructed using Kohlberg's theory [15] which consists of four good levels which are parsed based on their dimensions, aspects, and indicators. All items will be declared valid and reliable if the value of the correlation coefficient between items $(r)=0.3$, while for the reliable questionnaire reliability coefficient if the value of the reliability coefficient $(\alpha)=\geq 0.7$ (Azwar, 2012). The method of analysis of this study is a different test t-test using statistical tools. That is by comparing the significance values with table $t$. Moreover, it is said to be significant if the significance value is at the level $(\mathrm{p})=<0.05$, with an error rate of $5 \%$. While the distribution normality test is said to be normal or not. If the value is a sig. (p) $>0.05$, then the data is spread normally. The Ttest was used to analyze differences in assertiveness skills before and after giving assertive training to SDIT X teachers, West Jakarta. 


\section{$4 \quad$ Results}

The students in this study were divided into two groups, the control group, and the experimental group. Several students in the experimental group are 34 students and in the control group, amounted to 35 students.

The results of the t-test are obtained sig. $(p)=0,000 ;((p)<0.05)$, the hypothesis is accepted, there is a difference in the morality level of Islamic elementary school students in Jakarta based on the method of learning to play a role. The mean value of the experimental group is 11.000 and mean in the control group is 10.000 . It is shown that the mean of the experimental group is higher than the control group means there is a difference in the level of morality of students in the experimental group and the control group caused by the method of playing in the experimental group. Islamic student Elementary School who were given the role-playing method had a better level of morality compared to Jakarta Islamic Elementary School students who were not given the role-playing method.

Piaget believes that cognitive structures and cognitive abilities of children are the basis of their moral development [15]. With cognitive abilities possessed will help children understanding the problems in their social environment. Adler said that "life problems are always social". The function of healthy living is not only loving and working, but also feeling together with others and caring for their well-being (Alwisol, 2007). In carrying out its social role, Islamic elementary school students are certainly taught about good and evil deeds, reason, morals and so on. In morals, all good deeds are regulated, and evil deeds must be avoided. The moral will distinguish themselves from those around them.

This research proves that the role-playing method influences the moral improvement of Jakarta Islamic elementary school students through religious studies. There are 4 of the 6 aspects that are measured, the ability to understand Islam as a religion embraced, behave civilized or understand good behavior (honest, helpful, polite, respectful, etc.), the ability to distinguish good and bad behavior, and recognize and respect people's religion other. Other results found that there are differences amount students after the intervention. Before the role-playing method given to the experimental group, it was found that there amount six elementary school students who have a low-level morality. However, after given intervention as a role-playing method, the students who have a lowlevel morality become zero students or nonexistent. It is showing that ability the student to understand Isam is better. The same while in the others aspect like civilized behavior, the ability to distinguish good and evil and the ability to recognizing and respecting the religion of others there is increasing morality level.

Roleplay helps children reach outside their world and embrace the feelings, emotions, and plights of others. It is widely used in the lower grades to help children explore the world around them. When role-play is used in a school setting, students extend their knowledge of a subject by researching a character within a given course of study. Student interest is raised in subject matter, thus generating interest within the subject [4]. Students become active participants in their education rather than passive observers. It allows students to feel empathy for others when portraying a character involved in turbulent times in history [7]. The students can empower themselves to worship; they understand good behavior, can distinguish good and bad behavior, know rituals and religious holidays, and could respect the religion of others. Religious values become a solid foundation for children in the development of their moral life. The religious values are harmony in moral values

\section{Conclusion}

There is a difference in the morality level of Islamic elementary school students in Jakarta based on the method of learning to play a role. The mean value of the experimental group is 11.000 and mean in the control group is 10.000. It is shown that the mean of the experimental group is higher than the control group means there is a difference in the level of morality of students in the experimental group and the control group caused by the method of playing in the experimental group. Islamic student Elementary School who were given the role-playing method had a better level of morality compared to Jakarta Islamic Elementary School students who were not given the role-playing method.

\section{References}

[1] A. R. Shaleh, Pendidikan Agama dan Pembangunan Untuk Bangsa. Jakarta: Raja Grafindo Persada, 2005.

[2] Y. A. Rozali, 'Perbedaan Motivasi Belajar Ditinjau Dari Pembelajaran Berbasis Pengalaman (Studi Pada Mahasiswa Kelas Psikometri, Fakultas Psikologi Universitas Esa Unggul)', J. Psikol., vol. 11, no. 2, 2013.

[3] B. R. Joyce, M. Weil, and Em. Calhoun, Models of Teaching. Boston: Allyn \& Bacon, 2000.

[4] P. B. Poorman, 'Biography and Role Playing: Fostering Empathy in Abnormal Psychology', Teach. Psychol., vol. 29 , no. 1 , pp. 32-36, 2002. 
[5] P. Fogg, 'A History Professor Engages Students by Giving Them a Role in the Action', Chron. High. Educ., vol. 48, no. 12, 2001.

[6] J. McGregor, 'Effectiveness of Role Playing and Antiracist Teaching in Reducing Student Prejudice', J. Educ. Res., vol. 86, no. 4, pp. 215-226, 1993.

[7] S. Steindorf, 'A student researched website simulates escape from slavery', Christ. Sci. Monit., vol. 94, no. $13,2001$.

[8] R. Oxford and R. C. Scarcella, The Tapestry of Language Learning: The Individual in the Communicative Classroom. Heinle ELT, 1992

[9] J. E. Teahan, 'Role Playing and Group Experience to Facilitate Attitude and Value Changes among Black and White Police Officers', J. Soc. Issues, vol. 31, no. 1, pp. 35-45, 1975.

[10] E. T. Huyack, 'Teaching for Behavioral Change', Humanist Educ., vol. 14, no. 1, pp. 12-20, 1975.

[11] L. Ettkin and L. Snyder, 'A Model For Peer Group Counseling Based on Roleplaying', Sch. Couns., vol. 19, no. 2, pp. 215-218, 1972.

[12] K. Jones, Simulations in Language Teaching. Cambr: Cambridge University Press, 1982.

[13] C. V Lloyd, 'Engaging students at the top (without leaving the rest behind)', J. Adolesc. Adult Lit., vol. 42, no. 3, p. 184-1911, 1998.

[14] A. H. Cherif, S. Verma, and C. Somerville, 'From The Los Angeles Zoo To The Classroom: Transforming Real Cases Via Role-Play Into Productive Learning Activities’, Am. Biol. Teach., vol. 60, no. 8, pp. 613-617, 1998.

[15] J. H. Santrock, Educational Psychology. New York: McGraw-Hill, 2010. 